University of Nebraska - Lincoln

DigitalCommons@University of Nebraska - Lincoln

Faculty Publications from the Harold W. Manter Laboratory of Parasitology

$12-1976$

\title{
Some Platyhelminth Parasites of Sirens (Amphibia: Sirenidae) from North America
}

Daniel R. Brooks

University of Toronto,dnlbrooks@gmail.com

Richard L. Buckner

University of Nebraska - Lincoln

Follow this and additional works at: https://digitalcommons.unl.edu/parasitologyfacpubs

Part of the Parasitology Commons

Brooks, Daniel R. and Buckner, Richard L., "Some Platyhelminth Parasites of Sirens (Amphibia: Sirenidae) from North America" (1976). Faculty Publications from the Harold W. Manter Laboratory of Parasitology. 213.

https://digitalcommons.unl.edu/parasitologyfacpubs/213

This Article is brought to you for free and open access by the Parasitology, Harold W. Manter Laboratory of at DigitalCommons@University of Nebraska - Lincoln. It has been accepted for inclusion in Faculty Publications from the Harold W. Manter Laboratory of Parasitology by an authorized administrator of DigitalCommons@University of Nebraska - Lincoln. 


\title{
SOME PLATYHELMINTH PARASITES OF SIRENS (AMPHIBIA: SIRENIDAE) FROM NORTH AMERICA
}

\author{
Daniel R. Brooks \\ Gulf Coast Research Laboratory, P.O. Box A.G., Ocean Springs, Mississippi 39564 and \\ Richard L. Buckner \\ School of Life Sciences, University of Nebraska-Lincoln, Lincoln, Nebraska 68588
}

ABSTRACT: A new genus and species of digenean and a new species of cestode are described and a previously described species of digenean reported for the first time from Siren intermedia from Illinois. A new genus is proposed for a previously described digenean, and another known species of digenean reported from Siren lacertina in Florida. Progorgodera foliata from S. intermedia has a foliate hindbody characteristic of members of Phyllodistomum and multiple testes arranged in 2 longitudinal rows characteristic of members of Gorgodera. Ophiotaenia sireni from the same host resembles $O$. filaroides in number of testes, $O$. amphiumae and $O$. alternans in number of uterine branches, and $O$. grandis and O. marenzelleri in scolex size. Allassostomoides louisianaensis is reported for the first time from Siren intermedia. The new genus Cephalogonimoides is proposed for Cephalogonimus sireni from Siren lacertina, which differs from members of Cephalogonimus by having symmetrical testes, ceca extending to the posterior end of the body, an acetabulum twice as large as the oral sucker, and a muscular prepharynx; and by lacking a seminal receptacle. Telorchis stunkardi is reported from S. lacertina for the first time.

The amphibian genus Siren L. is represented in North America by two species, Siren lacertina L. and S. intermedia LeConte. Five species of adult platyhelminths have been reported from S. lacertina: Cercorchis (= Telorchis) sireni Zeliff 1937, Stomatrema guberleti Byrd 1937, Gorgodera minima Cort 1911, Cephalogonimus sireni Premvati 1969, and Ophiotaenia sp. (Zeliff, 1937; Walton, 1958; Premvati, 1969; Loftin, 1960). Manter (1938) reported Cephalogonimus amphiumae Chandler 1923 from Siren sp. To date, no adult platyhelminths have been reported from Siren intermedia.

From 1970 to 1975 adult platyhelminths were collected from Siren intermedia captured in southern Illinois. All specimens were fixed with AFA. Cestodes were first relaxed in cold tap water; digeneans were flattened with slight coverslip pressure. Worms were stained with Mayer's hematoxylin and mounted in Canada balsam. Measurements are in micrometers unless otherwise stated; figures were drawn with the aid of a drawing tube.

\section{DIGENEA}

\section{Progorgodera gen. n.}

Diagnosis: Gorgoderidae. Forebody tapered anteriorly, hindbody foliate. Oral sucker terminal with ventroterminal aperture. Pharynx absent; ceca

Received for publication 3 February 1976. simple, may be sinuous, terminating near posterior end of body. Acetabulum preequatorial. Testes multiple, postacetabular, intercecal, in 2 longitudinal rows. Seminal vesicle saccate; cirrus sac and cirrus absent. Genital pore median, postbifurcal. Ovary submedian, pretesticular. Seminal receptacle absent. Vitellaria compact, paired behind acetabulum. Uterus occupying most available space in hind body. Eggs embryonated. Excretory vesicle I-shaped. Parasites in urinary bladder of amphibians. Type species:

\section{Progorgodera foliata sp. n. (Figs. 1-2)}

Description (based on 16 specimens): Body 1.9 to $2.9 \mathrm{~mm}$ long by 0.9 to $1.4 \mathrm{~mm}$ wide at mid hindbody. Oral sucker 235 to 413 long by 211 to 390 wide. Acetabulum 30 to $35 \%$ body length from anterior end, 381 to 753 in diameter. Ratio of sucker widths 1:1.7 to 1.9. Esophagus 175 to 310 long; cecal bifurcation at mid forebody. Testes irregular, rows may extend to cecal tips. Genital pore immediately postbifurcal. Ovary irregular to lobed, 90 to 300 long by 50 to 285 wide. Mehlis' gland and Laurer's canal present. Vitellaria immediately postbifurcal, multilobed, lobes shallow. Extracecal uterine loops extending to ovarian level. Eggs 26 to 30 long by 18 to 22 wide. Excretory vesicle with associated gland cells, reaching nearly to level of ovary; pore terminal.

Host: Siren intermedia.

Site: Urinary bladder.

Locality: Roadside ditches, 2 miles north of Gorham, Jackson Co., Illinois.

Holotype: USNM Helm. Coll. No. 73520.

Paratypes: USNM Helm. Coll. No. 73521; Univ. Neb. State Mus., H. W. Manter Lab. No. 20268, and in collections of authors. 

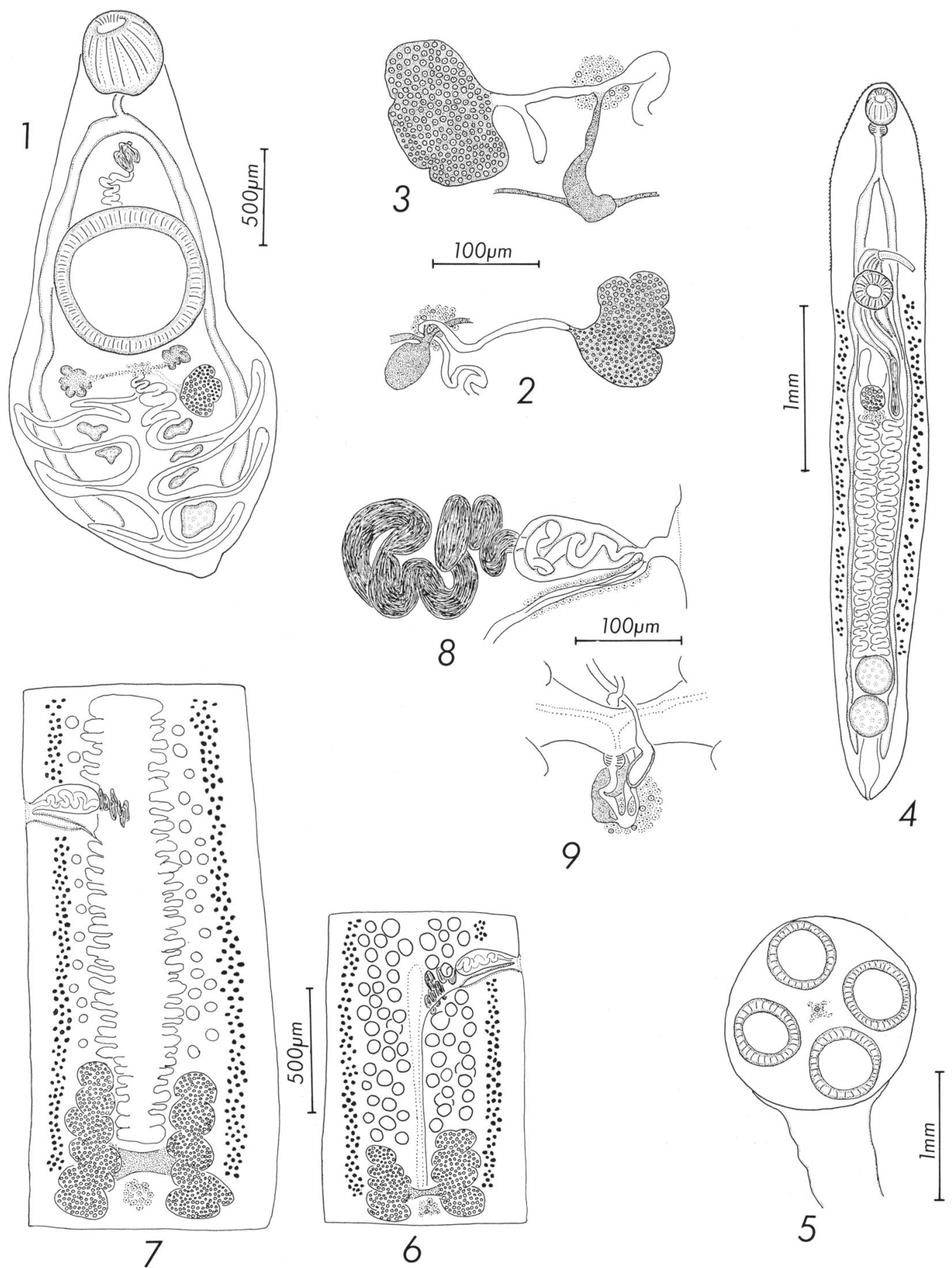

5

Fic:ures 1-9. Platyhelminths from sirens. 1. Progorgodera foliata, ventral view of holotype. 2. $P$. foliata, ootype. 3. Cephalogonimoides sireni, ootype. 4. Telorchis stunkardi, ventral viev. Figs. 5-9. Ophiotaenia sireni. 5. Scolex. 6. Mature proglottid. 7. Gravid proglottid. 8. Terminal genitalia. 9. Ootype. 
Etymology: The generic name means precursor to Gorgodera, a genus of amphibian digeneans, while the specific name refers to the foliate hindbody.

\section{Remarks}

In most of our specimens of $P$. foliata, the testes are dispersed and degenerate or inconspicuous. The holotype (Fig. 1) has four testes on the left side and two on the right, but we are not certain this is the normal configuration. By having multiple testes arranged in two longitudinal rows, $P$. foliata resembles members of Gorgodera Looss 1899 but by having a foliate hind body, it resembles members of Phyllodistomum Looss 1899. Because the new species exhibits the diagnostic features of two genera, the new genus is erected for it.

\section{Cephalogonimoides gen. n.}

Diagnosis: Cephalogonimidae. Body elongate, spinose. Oral sucker subterminal. Prepharynx muscular; pharynx present; esophagus short; ceca extending to posterior end of body. Acetabulum large, equatorial. Testes postacetabular, symmetrical. Cirrus sac may or may not reach acetabulum, enclosing tubular seminal vesicle, prostatic complex, and long ejaculatory duct. Genital pore terminal to oral sucker. Ovary submedian, posterolateral or lateral to acetabulum, lobed. Seminal receptacle absent. Laurer's canal and Mehlis' gland present. Vitellaria follicular, variable in extent, beginning at preacetabular level. Uterine coils occupying most available space in hind body. Eggs small. Excretory vesicle Y-shaped with lateral diverticula. Parasites in intestine of amphibians. Type and only known species: Cephalogonimoides sireni (Premvati 1969) comb. n.; syn. Cephalogonimus sireni Premvati 1969.

\section{REMARKS}

Premvati (1969) described Cephalogonimus sireni from five specimens collected from Siren lacertina in Florida. Examination of the holotype and paratype from the U. S. National Museum revealed the unique nature of the species. It resembles members of Cephalogonimus in possessing a terminal genital pore, large vitelline follicles, and Y-shaped excretory vesicle with lateral diverticula. It differs by having symmetrical testes, a lobed ovary, an acetabulum much larger than the oral sucker, ceca extending to the posterior end of the body, and a muscular prepharynx; and by lacking a seminal receptacle. Cephalogonimoides sireni was originally described as possessing a seminal receptacle, but examination of the type material showed that the structure described and figured as the seminal receptacle was in fact a loop of the uterus. The ootype region has been redrawn (Fig. 3). A ventral view of the holotype is figured in the original description. The holotype is mounted dorsal side up and drawn in this position, but captioned a ventral view (Premvati, 1969).

\section{Allassostomoides louisianaensis Christian and White 1973}

Host: Siren intermedia, new host.

Site: Rectum.

Locality: Roadside ditches, 2 miles north of Gorham, Jackson Co., Illinois.

Specimens deposited: 5, Univ. Neb. State Mus., H. W. Manter Lab. No. 20269.

\section{Remarks}

Allassostomoides louisianaensis was described from the pig frog, Rana grylio Stejneger, from Louisiana. Five specimens obtained from four sirens exhibited the features of $A$. louisianaensis as noted by Brooks (1975).

\section{Telorchis stunkardi Chandler 1923}

$$
\text { (Fig. 4) }
$$

Host: Siren lacertina, new host.

Site: Small intestine.

Locality: Vicinity of Miami, Florida.

Specimen deposited: 1, Univ. Neb. State Mus., H. W. Manter Lab. No. 20327.

\section{Remarks}

Chandler (1923) described this species from Amphiuma means in Louisiana; Wharton (1940) listed A. means and A. tridactylum as hosts for the species but gave no specific locality for the specimens which he utilized in his study.

\section{CESTOIDEA \\ Ophiotaenia sireni sp. n. (Figs. 5-9)}

Description (based on 3 worms with terminal proglottids and 9 without): Length of entire strobila 275 to $350 \mathrm{~mm}$, maximum width $1.0 \mathrm{~mm}$. Scolex globose, 1.6 to $1.9 \mathrm{~mm}$ wide, with darklystaining cells lining shallow apical depression. Suckers 4, simple, 445 to 730 in diameter. Neck 30 to $50 \mathrm{~mm}$ long. Immature proglottids wider than long. Mature proglottids 1.2 to $2.8 \mathrm{~mm}$ long by 0.7 to $0.9 \mathrm{~mm}$ wide; ratio of length to width 1: 0.3 to 0.6. Testes 37 to $93(65 \pm 14, \mathrm{n}=76)$ per proglottid, in anterior $4 / 5$. Vas deferens coiled in median portion of anterior fifth of proglottid. Cirrus sac 215 to 234 long; ratio of cirrus sac 
length to proglottid width $1: 3.3$ to 3.8 . Genital pore $1 / 6$ to $1 / 4$ proglottid length from anterior end; pores irregularly alternating. Vagina always posterior to cirrus sac, never crossing, surrounded by gland cells porally. Vaginal sphincter absent, distal portion of vagina dilated to form seminal receptacle. Ovary bialate with lobed wings, 600 to 750 wide, at posterior end of proglottid. Mehlis' gland prominent. Uterus preformed, causing separation of testes into 2 lateral fields. Vitellaria follicular, follicles medullary with some cortical, extending from anterior end of proglottid to midovary. Vitelline reservoir dorsomedian to ovarian isthmus. Gravid proglottids 1.9 to $3.2 \mathrm{~mm}$ long by 0.7 to $1.0 \mathrm{~mm}$ wide; ratio of length to width 1 : 0.3 to 0.4 . Uterine branches 42 to 97 ( $65 \pm 18$, $\mathrm{n}=44$ ) total. One large ventral uterine pore preformed immediately anterior to ovarian level. Eggs round, 23 to 32 in diameter; oncosphere 14 to 23 in diameter. Excretory system composed of paired dorsal and ventral vessels joined by anastomoses near posterior end of proglottid.

Host: Siren ir.termedia.

Site: Small intestine.

Locality: Roadside ditches, 2 miles north of Gorham, Jackson Co., Illinois.

Holotype: USNM Helm. Coll. No. 73518.

Paratypes: USNM Helm. Coll. No. 73519; Univ. Neb. State Mus., H. W. Manter Lab. No. 20015, 20267, and in collections of authors.

\section{REMARKS}

Ophiotaenia sireni differs from all other species in the genus by virtue of the highly lobed nature of the ovary and the restricted posterior extent of the vitellaria. Only Ophiotaenia marenzelleri (Barrois 1886) LaRue 1914 and $O$. grandis LaRue 1911 possess scoleces as large as that of $O$. sireni, but they differ in number of testes ( 150 to 250 vs. 37 to 93 ), position of genital pore (midproglottid vs. anterior $1 / 4$ to $1 / 6$ ), and relative width of ovary and uterus. Ophiotaenia sireni most closely resembles other members of the genus from caudate amphibians. It is similar to $O$. filaroides (LaRue 1909) LaRue 1914 in number of testes per proglottid and to $O$. alternans Riser 1942 and O. amphiumae (Zeliff 1932) Riser 1942 in number of uterine branches.

\section{ACKNOWLEDGMENTS}

The authors express appreciation to Dr. Brent B. Nickol, University of Nebraska-Lincoln for specimens of Ophiotaenia sireni; $\mathrm{Mr}$. Dwight Bowman, Tulane Medical Center for specimens of $O$. marenzelleri; Mr. Tom Mattis, Gulf Coast Research Laboratory for specimens of O. grandis; Dr. J. Ralph Lichtenfels, U. S. National Museum for the loan of type material of Cephalogonimoides sireni; and to Mary Hanson Pritchard, University of Nebraska State Museum for her aid in the preparation of the manuscript.

\section{LITERATURE CITED}

Brooks, D. R. 1975. A review of the genus Allassostomoides Stunkard 1924 (Trematoda: Paramphistomidae) with a redescription of A. chelydrae (MacCallum 1919) Yamaguti 1958. J Parasitol 61 : 882-885.

Chandler, A. C. 1923. Three new trematodes from Amphiuma means. Proc U S Nat Mus 63: $1-7$.

LofTiN, H. 1960. An annotated checklist of trematodes and cestodes and their vertebrate hosts from northwest Florida. Quart J Florida Acad Sci 23 : 302-314.

MANTER, H. W. 1938. A collection of trematodes from Florida amphibians. Trans Am Microsc Soc 57: 26-37.

Premvati, G. 1969. A new trematode Cephalogonimus sireni sp. nov. (Digenea: Cephalogonimidae) from Florida Mud-Eel, Siren lacertina. Proc Helminthol Soc Wash 36: 74-76.

Walton, A. C. 1958. Trematode parasites of Amphibia. II. Anat Rec 117: 640.

Wharton, G. W. 1940. The genera Telorchis, Protenes, and Auridistomum (Trematoda: Reniferidae). J Parasitol 26: 497-518.

ZeLiFF, C. C. 1937. A new species of trematode from the mud-eel (Siren lacertina). Proc U S Nat Mus 84: 223-226. 